\title{
The experiences of female ministers in counselling female rape survivors: A phenomenological study
}

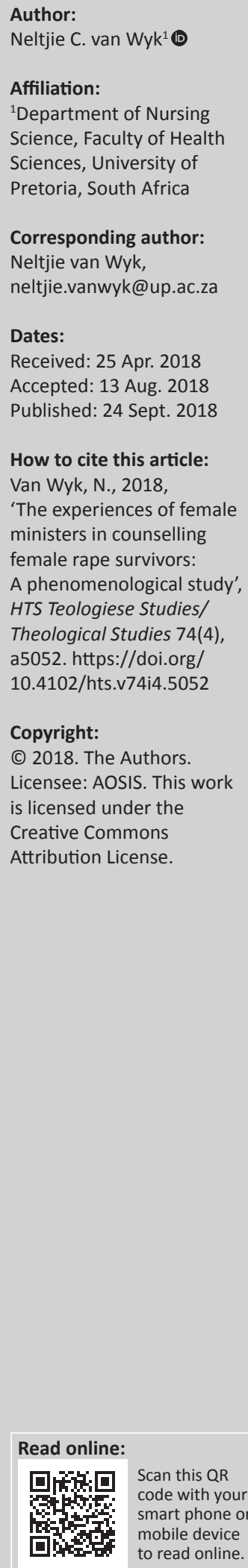

\begin{abstract}
Rape is an act of humiliation that leaves the survivors ashamed. They therefore often try and hide from others and rarely seek help. Informal discussions with female ministers revealed that some of them had counselled female rape survivors. A descriptive phenomenological study, aimed at exploring and describing the experiences of female ministers in counselling female rape survivors through individual interviews, was conducted. Six ministers were interviewed. They experienced the dichotomy of being a woman and being a minister during their encounter with rape survivors. As women, they became emotionally involved in the suffering of the rape survivors, and as ministers they experienced that prayer and scripture reading in collaboration with counselling promote healing. They also experienced that rape survivors perceived them as approachable because of their gender, but less approachable because of their status as ministers.
\end{abstract}

\section{Introduction}

Women in South Africa face the trauma of rape through their exposure to survivors or as survivors themselves. Although surveys indicate alarmingly high incidence rates of rape in South Africa (Machisa et al. 2011:5), many cases are not reported (Hirschauer 2014:92). It can thus be assumed that, on a daily basis, women in South Africa either read about rape in newspapers or are confronted with the dire consequences of rape when they or their friends, family members and acquaintances become survivors. Because of the brutality that they often endure, women who have been raped are called 'survivors of rape' (Black et al. 2011:2).

Rape is an act of humiliation and a means to display control over the victim (Stern 2012:61), with detrimental immediate and long-term effects on the physical and psychological well-being of the survivors (Campbell, Dworkin \& Cabral 2009:226). Survivors of rape are reluctant to report the incidents to the police (Vetten 2014:2) and often only consult healthcare services for medication to prevent sexually transmitted diseases (Ahrens et al. 2007:41).

Devoted Christian rape survivors may consult ministers (Ahrens et al. 2010:1255) to help them to restore their self-esteem (Robinson 2013:13) and to grow spiritually during the healing process (Gall et al. 2007:112).

Historically, churches were and are still associated with the support of people who suffer as a result of trauma and who need support in healing. Churches are important contributors to the well-being of their members (Adksion-Bradley et al. 2005:153). This study aimed to explore and describe the experiences of female ministers in counselling female rape victims.

\section{Methodology}

A descriptive phenomenology study in the constructivist paradigm was conducted to explore and describe the experiences of six female African ministers during the counselling of female rape survivors. They belonged to a church with predominantly African members. A phenomenon such as the focus of this study can best be studied through an exploration of the content of the intentional consciousness of the people involved (Solomon \& Higgins 1996:251). All consciousness is, according to Husserl, intentional as one is not only 'afraid but always afraid of something' (Hintikka 1995:78; Zahavi 2003:14). In this study, the participants did not only experience counselling but also attached meaning to their experiences. The content of the consciousness of the female ministers (as subjects in the phenomenological tradition) who were counselling (intentional action) female rape survivors (as objects in the same tradition) was explored and described (Zahavi 2003:14). Experiences are not without meaning, as human beings strive towards understanding their experiences and to attach meaning to them (Dahlberg, Dahlberg \& Nystr $m$ 2008:47). In this study, the researcher obtained data 
concerning the experiences of the ministers during counselling and the associated meaning of their experiences. Throughout the study, the focus was on 'how the phenomenon is and not what the informants said about it' (Dahlberg et al. 2008:47).

A relativist ontology was assumed, as multiple realities exist regarding counselling of female rape survivors, constructed through interaction between people (Denzin \& Lincoln 2005:35). The researcher believed that the phenomenon (experiences of the ministers in counselling of female rape survivors) could only be described by the ministers themselves during interaction with the researcher.

\section{Data collection}

Data were collected through unstructured phenomenological individual interviews. The participants (between 28 and 58 years old), who all held Bachelor of Arts Honours degrees and had received training in counselling, were challenged to 'unlock their consciousness to bring to surface' what their experiences were regarding the counselling of rape survivors (McNamara 2005:699). One question was asked of all participants, namely: 'How did you experience counselling female rape survivors?' Probing questions were used to obtain a rich description of their experiences and the meaning thereof. During data collection, the researcher 'bracketed' her pre-understanding of the phenomenon (Hamill \& Sinclair 2010:18) to focus on the 'sphere of consciousness' of the participants (Hintikka 1995:79).

\section{Data analysis}

In phenomenology research, the raw data obtained from the participants represents the natural dimension of the phenomenon and is often called the 'initial whole' (Carlsson et al. 2004:193). During the analysis of the raw data, the researcher dwelled long enough with it to get a clear understanding of the experiences and related meanings (Holloway \& Wheeler 2010:175). Intuiting was used to get a grasp of the essence of the experiences (Wojnar \& Swanson 2007:177). Through eidetic reduction, the natural dimension (initial whole) was abandoned for the phenomenological dimension (Zahavi 2003:39) of the experiences to enable the researcher to feel as if she 'had personally lived the participants' experience' (Kumar 2012:798). Through transcendental reduction, the researcher lifted herself 'off the ground to look down on the phenomenon' in order to get a clear understanding of the phenomenon (Rapport \& Wainwright 2006:232). The researcher 'imaginatively varied' the emerging essence of the phenomenon 'to distinguish essential features from those that were accidental or incidental' (Wertz 2005:168). Once the essence of the experiences and related meanings was revealed, the raw data were analysed, and themes that best described the 'whole' phenomenon were identified. Similar themes were linked to form constituents (meaning units) that substantiated the essence (new whole) of the phenomenon. The constituents were studied to ensure that the essence appeared in each constituent and that the constituents were essential parts of the essence.
In the description of the findings, the essence of the phenomenon is presented first and then the constituents. If it were presented the other way around, the reader of the description would not know 'what the constituents are constituents of' (Dahlberg et al. 2008:255). A literature review was performed to link the essence and the constituents to the existing knowledge base. In descriptive phenomenological research, the findings are presented first, followed by a literature discussion.

\section{Measures to ensure trustworthiness of the findings}

Trustworthiness of findings is achieved in phenomenological studies when 'bracketing' is applied consistently during data analysis. Once the essence and the supporting constituents were described, the last phase of 'bracketing', namely that of reintegration, took place. This phase focused on the reintegration of the bracketed information and a simultaneous comprehensive literature review to integrate the findings of the study into the knowledge base of the phenomenon (Gearing 2004:1432).

\section{Ethical consideration}

The Faculty of Health Sciences Research Ethics Committee of the University of Pretoria approved the proposal, and the moderator of the church granted the researcher permission to conduct the research. Prior to the onset of the interviews, written informed consent from each participant to take part in the research and permission to audio-record the interviews were obtained.

\section{Findings}

The essence of the experiences of the participants is the dichotomy of 'being a woman and being a minister' in the consciousness of the participants of themselves. This selfconsciousness is a defining feature of human beings. 'Each person constantly confronts the existence of other people, not simply as objects in his world, but as subjects who see him and judge him' (Cox 2009:37). The experiences of the participants during their interaction with rape survivors made them view rape as something that could happen to them too, and as a result they thought about it from the perspective of 'being a woman' whilst at the same time remembering that they were ministers of the church. They also had to respond to the needs of the rape survivors according to 'being a minister'. During their interaction with others, they became objects that others (in this case the survivors of rape) were conscious of and therefore also judged.

Two constituents (meaning units) substantiate the essence and will be described with excerpts from the transcribed interviews. All excerpts are written in inverted commas to show that the exact words of the participants are used.

\section{I am a woman}

According to one of the participants it was extremely difficult to counsel a rape survivor. She described it as 'the hardest thing I had to cope with'. All incidents of rape reminded 
them of their vulnerability as women and questions such as 'what if it was me?' and 'what if it was my sister or my kids' came to mind. One of the participants said: 'I will forget that I am a minister who prays for forgiveness and be a mother who will ask for revenge' if her daughter gets raped. They became overprotective of their children: 'I do not even trust male family members; my children should not sleep over at the homes of others; they should stay with $\mathrm{me}^{\prime}$. Even husbands were no longer trusted as some of the rape survivors were assaulted by their 'own family members and people they knew very well'. One participant was afraid that her baby could be sexually assaulted by her husband and she thus said: 'I did not want my husband to bathe our baby girl'. Another participant who described herself as happily married became suspicious of her husband:

'It is not that I did not trust my husband, but I kept thinking of what the husband [the perpetrator] had done to the victim [who he killed] and I thought that my husband can do it to me too.'

The participants experienced secondary trauma because of their emotional involvement. They viewed the women 'as if the survivors were blood relatives'. They explained that the experience 'goes deep into you' and 'you also get affected' to the point that 'you also get traumatised'. When older women or babies get raped, the secondary trauma gets worse. One participant said the following: 'I was affected very much by a rape incident in our community where young men raped an old pensioner - it shows a sense of evilness'.

The participants were disturbed by the self-blame of the rape survivors, who punished themselves with comments such as 'whether they were at the wrong places?' and therefore were easy targets and why they had 'been selected to be raped?' The rape survivors said that the rapists knew other women, too, so why did they 'choose to do this [rape] to me?' Was it because 'they [the victims] have done something wrong?'

The participants developed strong feelings of rejection of men who rape women. One of them described a rapist as 'an animal'. Some even developed extreme negative feelings about men in general: 'It influenced my view of men; I was so young when I helped the young girl'. Statements such as 'I never came to trust men' and 'I mistrust men' were used, while others believed that 'not all men are bad' and 'men in the church can be trusted'. One participant described her fellow ministers as 'my brothers; I can always approach them' and another one said: 'I am the only female minister in my congregation and I work with male ministers, but I am not afraid of them; they are good men'. One participant came up for all men and said: 'I trust men, because my husband was a good man'.

Because of their hatred for male rapists, rape survivors do not want to talk to male therapists. One participant described it as follows: 'She [the survivor] was angry; she hated men; she did not want a male doctor to help her; men should not come near her'. The participants believed it may be an important reason why rape survivors do not report rape to the police: 'They see all men as perpetrators; they do not want to have anything to do with them'. There are often only male police officers on duty and male attorneys in court 'who will ask interrogating questions that they [the rape survivors] will not be able to answer and the perpetrator will walk free'. When the survivor then returns home, she will no longer be able to keep the rape a secret and 'all will know, and she will be stigmatised'. According to one participant, the survivors would rather go to the hospital where there is a chance that a female nurse will treat the wounds and supply the medication to prevent the occurrence of sexually transmitted diseases: 'They go to the hospital for treatment not to get diseases'.

In response to a question on whether a male god can be trusted, three participants reacted as if they never thought of the possibility that God could not be trusted because of his gender. They stared at the researcher in utter surprise that she would ask the question. Only one participant admitted that there was a time when she could not rely on God, as he is a man and men do bad things to women: 'I doubt God, because he is a man; a man did it [raped a women] and God is also a man'. One participant responded with 'I never judged God for being a man', while another said 'I do not support feminist theology'.

\section{I am a minister}

The participants felt that as female ministers, they were the preferred providers of support to rape survivors. They were female and rape survivors prefer to talk to women and not to men: 'they find it easier to talk to a women minister of the church'. A female congregant once told one of the participants: 'I cannot talk to the other ministers [they are men], but I can talk to you'. As they are trained in doing counselling, they can offer the rape survivors the opportunity to relive the incident in a safe environment and help them to deal with it in a constructive manner, but they are also ministers who encourage healing through scripture reading and prayer: 'we can do counselling and scripture reading and prayer to renew the strength and faith of the person'. One participant was convinced that it should be a minister to support rape survivors and said that 'the victims are children of God and so is the minister'. She also added that women who are raped do not want people to know about their ordeal. They prefer to keep it a secret and for that reason, they do not want to go to counsellors who 'open a file for them' as the information that they then share gets written up and it is there for others to read. According to her, 'ministers are trained to listen; they have time for people in need; they do not write reports; what is said, stays with them'.

In general, people view ministers as 'persons who bring comfort and can help people to heal'. One participant described situations in which psychologists called her to do scripture reading and prayers for patients who demanded it: 'We [the psychologists] cannot pray to give the patients the hope that they need to cope with ... the patients want you to come and pray'. 
According to the participants, 'prayer should be part of counselling' as it 'renews the faith of the person' and 'people regain hope through prayer'. One participant described rape as a 'scar of the flesh and a scar of the soul'. The outer scar heals easily, and health professionals can assist the survivor to heal the scars. Only God can heal the inner scar and it takes time. Often the 'scar of the soul gets scratched' by newspaper reports and everyday activities that remind rape survivors of their rape. According to a participant, 'repeated scripture reading and prayer' are required to help survivors to heal. Another participant believed that the church through her ministers should remind rape survivors that 'we serve a God that heals' to help them to work towards rebuilding themselves and their self-esteem. The healing takes time and is 'a long process during which many prayers and scripture readings are required'. She emphasised that healing from rape cannot be purchased from God as the alternative churches promised:

'especially women go to these churches and pay money to get healing or other things; in our church we believe that God came to the world to save us; in the other churches one pays for his blood, but I believe that he washed us with his blood.'

According to her, people go to churches where visible miracle healing is done as they want all problems and thus also their experiences of rape to disappear quickly. Unfortunately, the healing of the scars of rape takes time and she pointed out that the survivors need to become actively involved in their healing by talking to people who they can trust: 'They need to open up to let the emotional scar heals'. Another participant recommended that they continued to 'trust God and when they move away from him, return to him'. When rape survivors feel as if no one can help them, a participant recommended that they should remember that 'Jesus Christ can heal the pain of a rape victim'. When the pain becomes unbearable and nobody can help them, Jesus Christ can: 'what we cannot do, Jesus Christ can do'. When rape survivors feel that 'their world is collapsing' and 'they have become useless' they could be reassured of 'God's love for them and God's omnipotence' and 'God is still there, and $\mathrm{He}$ loves them'. Although the participants experienced the turmoil of the rape survivors as heartbreaking, they remained extremely strong in their belief in God, as one of them emphasised: 'God's love is unconditional; we are all valued members of his congregation'.

Ministers preach about forgiveness and during the interviews some participants referred to how difficult it is for the survivors to forgive their rapists. They could not even forget what was done to them: 'The thing that happened is stored at the back of the mind; they cannot forget' and therefore they find it difficult to forgive. One of the participants described forgiveness as important for healing to take place: 'without forgiveness the victim cannot cope'. According to her, 'the victim should forgive for her own sake' and not to take the blame away from the perpetrator. According to another participant, it is, however, not for her to tell a rape survivor to forgive and forget: 'One cannot tell - forgive and forget'. According to this participant, only a female minister who had been raped and had forgiven the perpetrator could tell another rape survivor that it is possible to forgive and forget: 'a minister who has not been raped can be accused that she cannot help others to forgive'. The demands on one of the participants to lead people in forgiveness and healing became extremely difficult when both the victim and the perpetrator were known to her: 'I had to support both families; I had to visit the victim's and the perpetrator's families'. Everyone involved required support from her and, according to her, it was with 'God's grace and intervention' that she managed. One participant had to counsel a family who wanted to keep the rape of a young girl by her grandfather a secret. The perpetrator was a deacon in the congregation and the grandmother did not want their image to be tarnished:

'It was a family secret; it stayed in the family; they had to look after the child as her mother could not and the child is not allowed to disrupt the family who were good to her.'

The participant was disturbed by the attitude of the grandmother, knowing that it was the tip of the iceberg and that many families who attend church every week have similar secrets.

Not many congregants consult their ministers for counselling. One participant was devastated when a woman in her congregation asked her for a referral to a marriage counsellor: 'they do not realise that ministers can counsel and that we are available; they think that we can only preach'. According to her, the reason may be that there is too much respect in African congregations for the minister: 'In African churches the respect is too much; the minister is an important person; more important than congregants'. Another reason may also be that 'congregants are scared of the minister'. When ministers are not approachable, congregants have no choice but to keep their hurt to themselves. Congregants may also not trust the ministers, as one participant said: 'they do not trust the minister; she knows the people in the congregation'. Out of fear of gossip, the church and the ministers are not trusted to keep a rape secret. Rape survivors would rather go to people that they do not know and who they hope they will never see again for support: 'They rather go to someone who they will never see'.

It seemed as if the participants relied on readings from the New Testament to comfort rape survivors. Some of them said that they reassured the women that 'Jesus Christ heals' and 'is always present' and 'that Jesus is alive' and 'He understands and loves women'. One of the participants, however, mentioned that during counselling, she often referred to the women in the Old Testament: 'who were not seen as women; not seen as human beings; but rather as tools that men used' in order to remind them about the New Testament and Jesus Christ who came to our world and who does not differentiate between men and women. Her message to the women is: 'Jesus changed the lives of women; he understands and loves women'.

\section{Discussion}

The participants experienced the counselling of rape victims from two perspectives, namely from the perspective of 'being 
a woman' and from the perspective of 'being a minister'. They were conscious of their own vulnerability as women who could also become rape survivors and at the same time of their responsibility as ministers to counsel rape survivors. In addition, they were aware of the survivors' hesitation to trust them as ministers and to ask them for help. They were more approachable as women and less as ministers. The participants thus experienced the contradiction in the way other people (in this study the rape survivors) were conscious of them and who perceived them as women and as ministers. In the tradition of existentialism, they were subjects who were conscious of the 'others' and objects in the consciousness of the same 'others'.

Religious people are not spared trauma and thus also not spared from being raped (Vanderwoerd \& Cheng 2017:15). It happens even within congregations, between people who know each other or who are from the same family. When people of faith experience trauma such as rape survivors do, one hopes that they will go to the minister of the congregation with their brokenness (Armstrong 2016:118). It does, however, not always happen. The participants of this study experienced the reluctance of congregants to approach them as ministers for help to overcome their suffering. It seems that, according to research reports, the closer the ties between the rapist and the rape survivor, the less likely that survivors will approach the minister to intervene and to help them to heal (Chatters et al. 2017:147). The reasons why rape survivors do not make use of the support structures of the church seem to be common perceptions that rape is not discussed in the church and that a 'power hierarchy' exists between the clergy and the congregants (Yuvarajan \& Stanford 2016:599). It is easier for rape victims to approach close friends and family members for help (Bryant-Davis e al. 2015:125; Orchowski \& Gidycz 2015:809).

Churches do not have a reputable history regarding rape. The newspaper reports of clergy perpetrators of rape in the Roman Catholic Church tarnished the image of the church. The situation is aggravated when clergy classify women based on an Old Testament perspective as either 'angels, virgins or whores' because rape victims do not fit in the categories of angel or virgin, leaving only the label of whore. The Old Testament also refers to women as adulterers who use their sexuality to gain power over men. In the first chapters of Proverbs, Solomon advises young men not to allow women to seduce them (Yuvarajan \& Stanford 2016:598). This may be the reason why a recent study by Barnett, Sligar and Wang (2018:1230) found that more Roman Catholic and Protestant university students, and especially more men, than their atheist fellow students thought that rape survivors could be partially blamed for their own ordeal. Burchardt (2018:113) hoped to find a different situation in charismatic churches in South Africa. In these churches, men who become active members of congregations are referred to as 'transformed men' and Burchardt expected that the transformation would also lead to more respect for women. It was unfortunately not the case. At the time of her research, a Pentecostal pastor appeared in the Khayelitsha Magistrate Court in the Western Cape Province of South Africa charged with rape (Burchardt 2018:120).

Reference to rape can be found in the Bible. In the Old Testament, several cases of rape are reported. In some cases, the names of the rape victims are not known, such as the 10 wives of David who were raped by one of the sons of David, namely Absalom, to show that he had taken over his father's kingdom (2 Sm 13:23-39). The very same two people did nothing to support Tamar when she was raped by her brother, Amnon (2 Sm 13:1-22). David, as the father of Tamar, and Absalom, as the brother of Tamar, allowed her to become the scapegoat of a very dysfunctional family. Amnon ordered his servants to throw her out of his house and capitalised on her state of perpetual shame to disempower her to protect himself from accusations of having raped his own sister (Casey 2010:168). Feelings of shame disempower people and make them suffer in silence. It prevents rape survivors from talking about their ordeal and thus from getting help. At the same time, it protects the perpetrators from punishment (Crisp 2010:285).

Rape has far-reaching consequences for survivors. While physical scars may heal fairly easily, the emotional, spiritual and religious scars take much longer to heal (Crisp 2012:140). When they recall the rape incident or experience rejection from others, their suffering becomes overwhelming. It destructs their spiritual well-being and reinforces their suffering and feelings of worthlessness. Over time, it can become so severe that they feel incapable of embodying the divine on a spiritual and/or a religious level. Spiritual death occurs when the shame that rape survivors experience becomes 'rooted in the perception of self, causing the victim to review herself as dirty and immoral, no longer capable of embodying the divine' (Messina-Dysert 2012:130). Ministers have a huge responsibility towards rape survivors, and their contribution to help these women to regain self-respect and dignity is required long after the rape incidents. The participants of this study also talked about the long-term input that is required to help the women to come to terms with rape. They also referred to the challenges that rape survivors experience to forgive the perpetrators. According to Thorne (2001:441), all people, whether they are religious or see themselves as only spiritual, can be helped through pastoral counselling. Ministers can 'relate their faith to the existential struggles of those who seek their help'. In Africa, healing and the church are inseparable and African people, even those who are not devoted congregants, revert to the church when trauma is experienced as they expect that divine intervention is required for healing (Van Wyk 2011:6).

Much of the suffering of rape survivors is attributed to the so-called rape myths that refer to the false beliefs that shift the blame of rape from the perpetrators to the victims (Chapleau \& Oswald 2014:213; Suarez \& Gadalla 2010:2015). When women are raped without severe physical violence, or after they have used alcohol, or during visits to pubs or while 
they were walking alone at night, people sometimes question whether they did not at least partially contribute to the rape (Jaffe et al. 2017:16). Because of these myths, rape survivors may doubt their innocence and start to blame themselves (Ayala, Kotary \& Hetz 2018:111) or blame the situations that could have contributed to the rape (Osman 2016:775). Selfblame occurs more when the rapist is known to the survivor (Donde 2017:3528; Van der Bruggen \& Grubb 2014:530) or when the survivors did not physically fight back (Cook \& Messman-Moore 2018:523; Haugen et al. 2018:31). Some survivors are not sure whether they had been raped or sexually assaulted (Donde et al. 2018:14) and are uncertain about how to react. When rape survivors do not reach out to others for support because of rape myths, they also do not receive counselling. It may be the reason why the participants of this study experienced that not many rape survivors reach out to ministers for counselling. Churches need to do more to assist rape survivors. Collaboration with other sectors such as healthcare and education are required (Michau et al. 2015:1672). The participants also experienced that other professionals and specifically psychologists reached out to them for collaboration.

The trauma that rape survivors experience can impact negatively on the well-being of the people who try to help them (Dworkin, Sorell \& Allen 2016:750). The participants of this study reported that they became aware of their own vulnerability and that of their female family members during their interaction with rape survivors. One of them also referred to the dichotomy of being a minister and being a woman when she mentioned that should her daughter be raped, she would not be able to react in the way expected of a minister of the church. For the participants, being a woman and being involved in helping a woman who experienced such a trauma were disturbing experiences. In some cases, it provoked very negative feelings towards men as if all men were bad. An explanation for such perceptions could be that they related too closely to the rape survivors and that they through countertransference experienced the trauma that the survivors experienced. In such situations, the helper is no longer capable of helping the rape survivor (Ullman 2014:1138). The participants felt unsafe as they were women and the rape survivors were women. They also became aware of the possibility that they could be raped and that not all men are good. Such an increased awareness of the capacity of human beings to be cruel was experienced as secondary trauma (Sui \& Padmanabhanunni 2016:129).

The participants were convinced that ministers make a unique contribution through prayer and scripture reading to the healing of rape survivors. According to Harris, Edlund \& Larson (2006:397), prayers and a sense of belonging that are part of religious support are much needed by the humiliated survivors of rape. The church is historically associated with healing (Grundmann 2008:185) and supporting people during difficult times (Adksion-Bradley et al. 2005:150). Prayers by themselves and with others, reading the Bible and reciting verses of compassion help Christians to cope with psychological trauma (Smith, Bartz \& Richards 2007:10).
When psychological care is also required, it should be rendered in cooperation with the ministers (Bornsheuer, Henriksen \& Irby 2012:211).

Religious coping is experienced through 'praying for relief [and] seeking God's comfort through a faith community' (Bryant-Davis \& Wong 2013:677). Belonging to a congregation helps survivors of rape to restore their self-esteem. They become worthy of the support of others (Gall 2006:829) and prayers to God provide protection from trauma (Ahrens et al. 2010:1253).

\section{Conclusion}

The participants experienced the counselling of rape victims from the perspective of 'being a woman' and of 'being a minister'. As women, they became emotionally involved in the suffering of the rape survivors and even developed extreme negative perceptions of men. As ministers, they were aware of the contribution of prayer and scripture reading, in addition to counselling, in the healing of rape survivors. Unfortunately, rape survivors do not perceive ministers as approachable because of a distant relationship with them. All the participants would like to see ministers be available for congregants who have experienced trauma.

\section{Acknowledgements Competing interests}

The author declares that she has no financial or personal relationships which may have inappropriately influenced her in writing this article.

\section{References}

Adksion-Bradley, C., Johnson, D., Sanders, J.L., Duncan, L. \& Holcomb-McCoy, C., 2005, 'Forging a collaborative relationship between the black church and the counselling profession', Counselling and Values 49, 147-154. https://doi.org/10.1002/j.2161007X.2005.tb00261.x

Ahrens, C.E., Abeling, S., Ahmad, S. \& Hinman, J., 2010, 'Spirituality and well-being: The relationship between religious coping and recovery from sexual assault', Journal of Interpersonal Violence 25(7), 1242-1263. https://doi.org/10.1177/ 0886260509340533

Ahrens, C.E., Campbell, R. \& Ternier-Thames, N.K., Wasco, S.M. \& Sefl, T., 2007 'Deciding whom to tell: Expectations and outcomes of rape survivors' first disclosures', Psychology of Women Quarterly 31, 38-49. https://doi.org/10.1111/ j.1471-6402.2007.00329.x

Armstrong T.D., 2016, 'African-American congregational care and counselling: Transcending universal and culturally-specific barriers', Journal of Pastoral Care \& Counselling 70(2), 118-122. https://doi.org/10.1177/1542305016634666

Ayala, E.E., Kotary, B. \& Hetz, M., 2018, 'Blame attributions of victims and perpetrators: Effects of victim gender, perpetrator gender, and relationship', Journal of Interpersonal Violence 33(1), 94-116. https://doi.org/10.1177/0886260515599160

Barnett, M.D., Sligar, K.B. \& Wang, C.D.C., 2018, 'Religious affiliation, religiosity, gender, and rape myth acceptance: Feminist theory and rape culture', Journal of Interpersonal Violence 33(8), 1219-1235. https://doi.org/10.1177/0886260516665110

Black, M.C., Basile, K.C., Breiding, M.J., Smith, S.G., Walters, M.L., Merrick, M.T. et al., 2011, The national intimate partner and sexual violence survey (NISVS): 2010 Summary Report, National Center for Injury Prevention and Control, Centers for Disease Control and Prevention, Atlanta, GA

Bornsheuer, J.N., Henriksen, R.C. \& Irby, B.J., 2012, 'Psychological care provided by the church: Perceptions of Christian church members', Counselling and Values 57 199-213. https://doi.org/10.1002/j.2161-007X.2012.00017.x

Bryant-Davis, T., Ullman, S., Tsong, Y., Anderson, G., Counts, P., Tillman, S. et al., 2015, 'Healing pathways: Longitudinal effects of religious coping and social support on PTSD symptoms in African American sexual assault survivors', Journal of Trauma \& Dissociation 16, 114-128. https://doi.org/10.1080/15299732.2014.969468

Bryant-Davis, T. \& Wong, E.C., 2013, 'Faith to move mountains: Religious coping, spirituality, and interpersonal trauma recovery', American Psychologist 675-684. https://doi.org/10.1037/a0034380 
Burchardt, M., 2018, 'Saved from hegemonic masculinity? Charismatic Christianity and men's responsibilization in South Africa', Current Sociology 66(1), 110-127. and men's responsibilization in South Africa',
https://doi.org/10.1177/0011392117702429

Campbell, R., Dworkin, E. \& Cabral, G., 2009, 'An ecological model of the impact of sexual assault on women's mental health', Trauma, Violence \& Abuse 10, 225246. https://doi.org/10.1177/1524838009334456

Carlsson, G., Dahlberg, K., Lützen, K. \& Nystrőm, M., 2004, 'Violent encounters in psychiatric care: A phenomenological study of embodied caring knowledge' Issues in Mental Health Nursing 25, 191-217. https://doi.org/10.1080/ 01612840490268324

Casey, K.L., 2010, 'What part of 'no' don't you understand? Talking the tough stuff of the Bible: A creative reading of the rape of Tamar -2 Sam. 13:1-22', Feminist Theology 18(2), 160-174. https://doi.org/10.1177/0966735009348549

Chapleau, K., M. \& Oswald, D.L., 2014, 'A system justification view of sexual violence: Legitimizing gender inequality and reduced moral outrage are connected to Legitimizing gender inequality and reduced moral outrage are connected to greater rape myth acceptance', Journal of Traum
https://doi.org/10.1080/15299732.2014.867573

Chatters, L.M., Taylor, R.J., Woodward, A.T., Bohnert, A.S.B., Peterson, T.L. \& Perron, B.E., 2017, 'Differences between African Americans and Non-Hispanic Whites utilization of clergy for counselling with serious personal problems', Race, Social Problems 9, 139-149. https://doi.org/10.1007/s12552-017-9207-z

Cook, N.K. \& Messman-Moore, T.L., 2018, 'I said no: The impact of voicing nonconsent on women's perceptions of and responses to rape', Violence Against Women 24(5), 507-527. https://doi.org/10.1177/1077801217708059

Cox, G., 2009, How to be an existentialist or how to get real, get a grip and stop making excuses, Continuum Books, London.

Crisp, B.R., 2010, 'Silence and silenced: Implications for the spirituality of survivors of sexual abuse', Feminist Theology 18(3), 277-293. https://doi.org/10.1177/ sexual abuse', Femini
0966735009360386

Crisp, B.R., 2012, 'The spiritual implications of sexual abuse: Not just an issue for religious women?', Feminist Theology 20(2), 133-145. https://doi.org/10.1177/ 0966735011425301

Dahlberg, K., Dahlberg, H. \& Nystrőm, M., 2008, Reflective lifeworld research Studentlitteratur, Lund.

Denzin, N.K. \& Lincoln, Y.S., 2005, 'Paradigms and perspectives in contention', in N.K. Denzin \& Y.S. Lincoln (eds.), The Sage handbook of qualitative research, 3rd edn., pp. 183-190, Sage, Thousand Oaks, CA

Donde, S.D., 2017, 'College women's attributions of blame for experiences of sexual assault', Journal of Interpersonal Violence 32(22), 3520-3538. https://doi. org/10.1177/0886260515599659

Donde, S.D., Ragsdale, S.K.A., Koss, M.P. \& Zucker, S.N., 2018, 'If it wasn't rape, was it sexual assault? Comparing rape and sexual assault acknowledgement in college women who have experienced rape', Violence Against Women https://doi. org/10.1177/1077801217743339

Dworkin, E.R., Sorell, N.R. \& Allen, E.A., 2016, 'Individual- and setting-level correlates of secondary traumatic stress in rape crisis center staff', Journal of Interpersonal Violence 31(4), 743-752. https://doi.org/10.1177/0886260514556111

Gall, T.L., 2006, 'Spirituality and coping with life stress among adult survivors of childhood sexual abuse', Child Abuse and Neglect 30, 829-844. https://doi. org/10.1016/j.chiabu.2006.01.003

Gall, T.L., Basque, V., Damasceno-Scott, M. \& Vardy, G., 2007, 'Spirituality and the current adjustment of adult survivors of childhood sexual abuse', Journal for the
Scientific Study of Religion 46(1), 101-117. https://doi.org/10.1111/j.1468Scientific Study of
5906.2007.00343.x

Gearing, R.E., 2004, 'Bracketing in research: A typology', Qualitative Health Research 14, 1429-1452. https://doi.org/10.1177/1049732304270394

Grundmann, C.H., 2008, 'Mission and healing in historical perspective', International Bulletin of Missionary Research 32(4), 185-188. https://doi.org/10.1177/ 239693930803200404

Hamill, C. \& Sinclair, H., 2010, 'Bracketing - Practical considerations in Husserlian phenomenological research', Nurse Researcher 17(2), 16-24. https://doi. org/10.7748/nr2010.01.17.2.16.c7458

Harris, K.M., Edlund, M.J. \& Larson, S.L., 2006, 'Religious involvement and the use of mental health care', HSR: Health Services Research 41(2), 395-410. https://doi.org/ 10.1111/j.1475-6773.2006.00500.x

Haugen, A.D., Rieck, S.M., Salter, P.S. \& Phillips, N.L., 2018, 'What makes it rape? A lay theories approach to defining rape among college students', Basic and Applied Social Psychology 40(1), 18-35. https://doi.org/10.1080/01973533.2017.1398091

Hintikka, J., 1995, 'The phenomenological dimension', in B. Smith \& D.W. Smith (eds.), Cambridge companion to Husserl, pp. 78-105, Cambridge University Press, Cambridge.

Hirschauer, S., 2014, 'Rape and the state: Sexual violence and its political narrative and othering in $21^{\text {st }}$ Century South Africa', Africa Insight 44(1), 84-102.
Holloway, I. \& Wheeler, S., 2010, Qualitative research in nursing and healthcare, 4th edn., Wiley-Blackwell Publishers, New York.

Jaffe, A.E., Steel, A.L., DiLillo, D., Messman-Moore, T.L. \& Gratz, K.L., 2017, 'Characterizing sexual violence in intimate relationships: An examination of blame attributions and rape acknowledgment', Journal of Interpersonal Violence. https://doi.org/10.1177/0886260517726972

Kumar, A., 2012, 'Using phenomenological research methods in qualitative health research', International Journal of Human Sciences 9(2), 790-804.

Messina-Dysert, G., 2012, 'Rape and spiritual death', Feminist Theology 20(2), 120132. https://doi.org/10.1177/0966735011425305

Machisa, M., Jewkes, R., Morna, C.L. \& Rama, K., 2011, The war at home - GBV indicators project, Gender Links, Johannesburg.

McNamara, M.S., 2005, 'Knowing and doing phenomenology: The implications of the critique of "nursing phenomenology" for a phenomenological inquiry: A paper critique of "nursing phenomenology" for a phenomenological inquiry: A paper
discussion', International Journal of Nursing Studies 42, 695-704. https://doi. org/10.1016/j.jinurstu.2005.02.002

Michau, L., Horn, J., Bank, A., Dutt, M. \& Zimmerman, C., 2015, 'Prevention of violence against women and girls: Lessons from practice', Lancet 385, 1672-1684. https:// doi.org/10.1016/S0140-6736(14)61797-9

Orchowski, L.M. \& Gidycz, C.A., 2015, 'Psychological consequences associated with positive and negative responses to disclosure of sexual assault among college women: A prospective study', Violence Against Women 21(7), 803-823. https:// doi.org/10.1177/1077801215584068

Osman, S.L., 2016, 'Predicting rape victim empathy based on rape victimization and acknowledgement labelling', Violence Against Women 22(7), 767-779. https:// doi.org/10.1177/1077801215610864

Rapport, F. \& Wainwright, P., 2006, 'Phenomenology as a paradigm of movement', Nursing Inquiry 13, 228-236. https://doi.org/10.1111/j.1440-1800.2006.00325.x

Robinson, L., 2013, 'Is the church safe for survivors? Examining the church's role in opposing rape culture', Mutuality Spring, 12-14.

Smith, T.B., Bartz, J. \& Richards, P.S., 2007, 'Outcomes of religious and spiritual adaptations to psychotherapy: A meta-analytic review', Psychotherapy Research 1, 1-13. https://doi.org/10.1080/10503300701250347

Solomon, R.C. \& Higgens, K.M., 1996, A short history of philosophy, Oxford University Press, New York.

Stern, V., 2012, 'Dealing with rape in a new political landscape', Medico-Legal Journa 80(2), 60-68. https://doi.org/10.1258/mlj.2012.012003

Suarez, E. \& Gadalla, T.M., 2010, 'Stop blaming the victim: A meta-analysis on rape myths', Journal of Interpersonal Violence 25(11), 2010-2035. https://doi.org/ 10.1177/0886260509354503

Sui, X-C. \& Padmanabhanunni, S., 2016, 'Vicarious trauma: The psychological impact of working with survivors of trauma for South African psychologists', Journal of Psychology in Africa 26(2), 127-133. https://doi.org/10.1080/14330237.2016.11 63894

Thorne, B., 2001, 'The prophetic nature of pastoral counselling', British Journa of Guidance and Counselling 29(4), 435-445. https://doi.org/10.1080/0306988 of Guidance

Ullman, S.E., 2014, 'Interviewing therapists about working with sexual assault survivors: Researcher and therapist perspectives', Violence Against Women 20(9), 1138-1156. https://doi.org/10.1177/1077801214549639

Van der Bruggen, M. \& Grubb, A., 2014, 'A review of the literature relating to rape victim blaming: An analysis of the impact of observer and victim characteristics on attribution of blame in rape cases', Aggression and Violent Behavior 19, 523-531. https://doi.org/10.1016/j.avb.2014.07.008

Vanderwoerd, J.R. \& Cheng, A., 2017, 'Sexual violence on religious campuses', Canadian Journal of Higher Education 47(2), 1-21.

Van Wyk, I.W.C., 2011, 'Finding a place for Jesus as healer in Reformed mission in Africa', HTS Teologiese Studies/Theological Studies 67(1), 1-8. https://doi.org/ 10.4102/hts.v67i1.864

Vetten, L., 2014, Rape and other forms of sexual violence in South Africa, Policy brief 72 , Institute for Security Studies, Pretoria.

Wertz, F.J., 2005, 'Phenomenological research methods for counselling psychology', Journal of Counselling Psychology 52(2), 167-177. https://doi.org/10.1037/0022 0167.52.2.167

Wojnar, D.M. \& Swanson, K.M., 2007, 'Phenomenology: An exploration', Journal of Holistic Nursing 25(3), 172-180. https://doi.org/10.1177/0898010106295172

Yuvarajan, E. \& Stanford, M.S., 2016, 'Clergy perceptions of sexual assault victimization', Violence Against Women 22(5), 588-608. https://doi.org/10.1177/ 1077801215605919

Zahavi, D., 2003, Husserl's phenomenology, Stanford University Press, Stanford. 